\title{
Application of a degree-day model to reconstruct Pleistocene glacial climates
}

\author{
Philip D. Hughes *, Roger J. Braithwaite \\ Geography, School of Environment and Development, The University of Manchester, Manchester M13 9PL, UK \\ Received 29 November 2006 \\ Available online 4 December 2007
}

\begin{abstract}
There is empirical evidence of a nonlinear relation between annual precipitation, or accumulation, and summer mean temperature at the equilibrium line altitude (ELA) on glaciers around the world. The degree-day model gives a similar relation between accumulation and summer temperature, although instead of a single universal curve there is a family of curves depending upon the annual temperature range. Furthermore, the degree-day model also gives nonlinear relations between accumulation and annual mean temperature. Thus, estimations of accumulation can be made from both summer and annual temperatures at the ELA of former reconstructed glaciers, such as those in Greece. This is particularly useful since these climatic variables have major implications for biological proxies, such as vegetation history indicated in the pollen record, and for periglacial proxies, such as permafrost distributions indicated in the geomorphological record. The close relationship between glaciers and climate provides one of the most precise methods for reconstructing former climates and offers considerable potential for resolving our understanding of Pleistocene cold-stage climates.
\end{abstract}

(C) 2007 University of Washington. All rights reserved.

Keywords: Degree-day model; Glaciation; Palaeoclimate; Greece

\section{Introduction}

The relationship between glaciers and climate is fundamental to understanding glacier behavior. There are well-established relationships between annual precipitation, or accumulation, and summer mean temperature at the equilibrium line altitude (ELA) on glaciers around the world (Ahlmann, 1924, 1948; Loewe, 1971; Leonard, 1989; Ohmura et al., 1992). Various forms of this relationship have been applied to reconstructions of Pleistocene glaciers (Sutherland, 1984; Ballantyne, 1989, 2002a; Hughes, 2002; Hughes et al., 2006a) and the relationship provides one of the most useful approaches for palaeoclimate reconstruction using glacial evidence. However, the utility of the relationship between annual precipitation, or accumulation, and summer mean temperature at the equilibrium line altitude (ELA) for palaeoclimate work is constrained by the need to isolate one of these variables in order to derive the other. In particular, it is frequently very difficult to isolate summer temperatures for palaeoglaciological work and it is even more difficult to isolate values of precipitation in mountainous regions.

\footnotetext{
* Corresponding author.

E-mail address: philip.hughes@manchester.ac.uk (P.D. Hughes).
}

Other proxy records that can help isolate the accumulation or temperature variables include temperature or moisture-sensitive biological evidence such as coleoptera (Miller and Elias, 2000), ostracods (Frogley et al., 2001) and pollen (Peyron et al., 1998). However, these records rarely provide precise estimates of palaeoclimate variables but provide only ranges of values. Furthermore, these records are commonly far removed from a former glacier site high in the mountains. Another method of deriving one or more palaeoclimate variables at former glacier sites is through periglacial geomorphology-especially using evidence of the distribution of permafrost. As with glaciers, there is a close empirical relationship between permafrost, and associated landforms, and climate, particularly mean annual temperature and precipitation (Haeberli, 1985; Humlum, 1998). For example, features such as periglacial rock glaciers have been shown to have lower boundaries associated with the altitudinal limits of discontinuous permafrost and approximately the $-2^{\circ} \mathrm{C}$ mean annual isotherm. This fact was exploited by Hughes et al. (2003) to reconstruct former mean annual temperatures based on relict rock glacier evidence in Greece during the last (Tymphian) cold stage. However, because permafrost evidence is associated with mean annual temperatures, it is difficult to use these palaeoclimate data for understanding the 
glacier-climate record, where it is summer and not annual temperatures that are associated with ablation on glaciers. Hughes et al. (2006a) attempted to resolve these problem for Late Pleistocene glacier-climate reconstructions in Greece by making assumptions about the annual range of monthly mean temperatures and distributing the annual mean over a sinusoidal distribution to derive a value for the summer temperature mean. This approach then enabled the calculation of annual precipitation (strictly, winter balance plus summer precipitation; see Ohmura et al., 1992).

Unlike the approach of Hughes et al. (2006a), which relied on the empirical regression of Ohmura et al. (1992) to relate summer temperature and precipitation, this paper presents a degree-day model to describe mass balance on glaciers in Greece. Glaciers formed in the mountains of the Mediterranean on multiple occasions during the Pleistocene cold stages (Hughes et al., 2006b). These glaciers were small compared with the vast ice masses of the Alps and northern Europe, although substantial local ice caps, ice fields and valley glaciers formed in many Mediterranean mountain areas, such as in the Pindus Mountains of Greece (Hughes et al., 2006c) (Fig. 1). The small Pleistocene Mediterranean glaciers would have been particularly sensitive to climate change and their geomorphological record provides an important archive of cold-stage climates.

The glacial history of Greece has recently been the focus of intensive investigation and several papers have provided new insight into the extent, the timing and the climatic significance of Pleistocene glaciers in the Pindus Mountains (Woodward et al., 2004; Hughes et al., 2003, 2006a,c,d, 2007). The oldest, most extensive glaciation was characterized by ice fields and valley glaciers, and glacial deposits contain secondary calcites yielding ages $>350,000 \mathrm{yr}$. This glaciation has been assigned to the Skamnellian Stage (Marine Isotope Stage [MIS] 12; 480$430 \mathrm{ka}$ ). Higher, less extensive glacial deposits were formed by cirque and valley glaciers during the Vlasian Stage (MIS 6; 190-126.6 ka); while the most recent glaciers in Greece formed in the highest cirques during the Tymphian Stage (MIS 5d-2; $111-11.5 \mathrm{ka})$. The last glaciers in Greece are thought to have formed during the late glacial, possibly during the Younger Dryas (12.9-11.5 ka) (Hughes et al., 2006d).

The aim of this paper is to demonstrate the use of a degreeday model for reconstructing palaeoglacier climates. Degreeday modeling has been extensively applied to present glaciers (e.g., Huybrechts et al., 1991; Braithwaite et al., 2003; Braithwaite et al., 2006) and has recently been applied to former glaciers (e.g., Brugger, 2006). The degree-day model in the paper presented here is applied to former Pleistocene glaciers in Greece to reconstruct former temperature-precipitation conditions during multiple cold stages. Comparisons are then made with earlier reconstructions made using the wellestablished regression between winter balance plus summer precipitation and summer temperature at the ELA of modern glaciers (Hughes et al., 2006a,d, 2007).

\section{The field area}

This paper focuses on Mount Tymphi (2497 m a.s.1., with all altitudes given here above modern sea level) in the northern
Pindus Mountains, Greece. Mount Tymphi is formed largely in limestones with flysch present on the lower slopes. Glacial landforms are widely preserved and Pleistocene glaciation has combined with karstic processes to form a classic glaciokarst landscape (Waltham, 1978). The high mountain climate is characterized by mild wet summers and cold snowy winters with snow cover remaining until July in places. The mean annual air temperature at Ioannina (483 $\mathrm{m}$ a.s.1.), ca. $50 \mathrm{~km}$ from Mount Tymphi, was $14.3^{\circ} \mathrm{C}$ with mean annual precipitation of $1078 \mathrm{~mm}$ over the period 1961-1990 (World Meteorological Organisation, 1998). On the southern slopes of Mount Tymphi, annual precipitation averaged $1721 \mathrm{~mm}$ for the period 19351970 at Skamnelli (1180 m a.s.1.) and values of up to $2500 \mathrm{~mm}$ are likely on the mountains (Fotiadi et al., 1999). In this paper, temperature data at the reconstructed glacier ELAs are extrapolated from the gridded climatology provided in New et al. (1999).

\section{Pleistocene glacier reconstruction in Greece-methods}

Geomorphological evidence of glaciation was mapped in the field onto 1:10,000 base maps. Morpholithostratigraphy and pedostratigraphy was used to separate glacial sedimentary units and secondary calcites within these units were dated using uranium-series techniques to understand the timing of glaciation (Hughes et al., 2006c). Lower glacier margins were traced on the basis of moraine positions. Upper glacier margins were often not well defined in the geomorphological record and former glacier outlines were usually extrapolated from the lower glacier areas to fit cirque and valley morphometry. Glacier contours were drawn by joining points of equal altitude at the former glacier margins following the pattern on modern glaciers, whereby contours are slightly convex near the snout and concave in the glacier source area (Sissons, 1974, 1977).

Glacier equilibrium line altitudes were reconstructed using a variation on the accumulation area method. It was refined using the methods outlined by Osmaston (2002) for the Rwenzori Mountains in central Africa. This involves taking the altitudes corresponding to 11 evenly spaced accumulation-area ratios of between 0 and 1 ( $0,0.1,0.2,0.3,0.4,0.5,0.6,0.7,0.8,0.9,1.0)$. The standard deviation at each AAR for groups of glaciers was calculated and the AAR with the lowest standard deviation was chosen. The altitude of the snout area within a group of glaciers is likely to vary considerably depending on the hypsometry of the former glaciers. This is why moraine altitude is a poor comparative measure of glacier altitude. Glacier source areas will also vary, though to a lesser degree, and will be a function of the altitude of the mountain watershed-which is often controlled by tectonic and structural geology. As a result, groups of glaciers will tend to produce an asymmetrical Ushaped curve when standard deviation of altitude is plotted against AAR.

Paraglacial processes including talus accumulation, debris flows and mass failure of valley sides (Church and Ryder, 1972; Ballantyne, 2002b), as well as post-glacial erosion, all act to disguise evidence of glaciation in the geomorphological record. This problem becomes more acute the older the glaciation. 


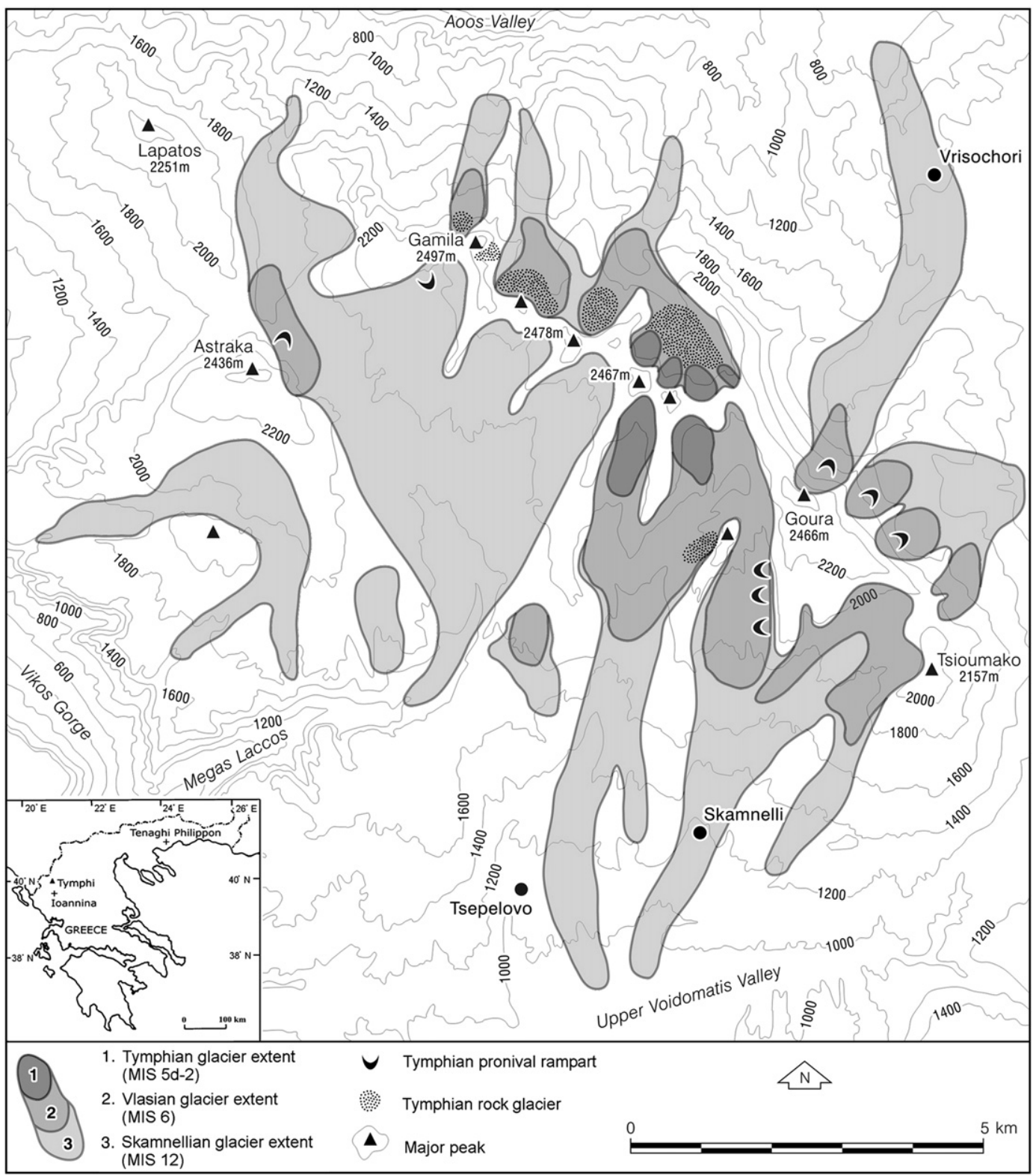

Figure 1. Pleistocene glaciers on Mount Tymphi in the northern Pindus Mountains, Greece (after Hughes et al., 2007).

However, given that the oldest glacial landforms were formed by the largest glaciers, errors in reconstructing ELAs are often smoothed by the large surface area of the former ice cover.

A further problem is that of tectonic uplift and sea-level change. However, since uplift in Epirus is estimated at ca. 40$80 \mathrm{~m}$ per 100,000 yr (King and Bailey, 1985), then tentative corrections can be made for uplift. Sea levels, on the other hand, would have been variable depending on the glaciation under consideration. At the height of the last glaciation, during the Tymphian Stage (MIS 2), global eustatic sea levels are known to have been ca. 130-135 m lower than today (Yokoyama et al., 2000). In fact, the whole northern section of the Adriatic Sea would have been land ca. 20,000 yr ago (van Andel and Shackleton, 1982). Lower eustatic sea levels during cold stages imply that ELA values reconstructed using modern sea level underestimate the real ELA values based on cold-stage sea level.
Beyond 325,000 yr ago, uplift of $40 \mathrm{~m}$ per 100,000 yr outstrips a cold-stage eustatic sea-level depression of $130 \mathrm{~m}$ and therefore reconstructed ELAs are likely to be overestimated rather than underestimated. For example, during the Skamnellian Stage, reconstructed ELAs may be up to $250 \mathrm{~m}$ higher than the "real" ELAs depending on the rate of uplift and the timing of the glacial maximum. However, given that global ice volumes were greater during MIS 12 than during any subsequent glacial stage, it is possible that the figure is less than this because of glacioeustatic sea-level lowering in excess of $130 \mathrm{~m}$. However, none of these factors affect the palaeoclimate reconstructions presented here. This is because under an assumption of uniform uplift, different positions in the landscape can be assumed to have been separated by the same elevation throughout the last few hundred thousand years, irrespective of their relative position above sea level. 


\section{Glaciers and climate-a degree-day model approach}

The degree-day model is based upon the notion that glacier melting occurs when air temperatures $1-2 \mathrm{~m}$ above the glacier surface are above the melting point $\left(0^{\circ} \mathrm{C}\right)$. The total melt over a period at some point is therefore proportional to the sum of positive temperatures at the same point, i.e., the positive degreeday total. It is not actually necessary to sum daily temperature data because it is possible to calculate monthly degree-day totals from the monthly mean temperature, assuming that temperature is normally distributed within the month (Braithwaite, 1985). Melt is linked to positive degree-day total by the positive degree-day factor, with higher values for ice than for snow (Braithwaite, 1995). Therefore, there is greater melting if the surface material is ice compared with snow, under similar temperature conditions. The degree-day model is widely used for modelling the mass balance of the Greenland ice sheet, following Huybrechts et al. (1991), but has also been applied to mountain glaciers and ice caps (Braithwaite et al., 2003; Raper and Braithwaite, 2006).

The paper presented here demonstrates the main features of the degree-day model using a simplified version (Reeh, 1989) where monthly mean temperature follows a sinusoidal curve throughout the year, defined by the annual temperature range. Snow melt is calculated using a degree-day factor of $4 \mathrm{~mm}$ day $^{-1}{ }^{\circ} \mathrm{K}^{-1}$ (Braithwaite et al., 2006) and annual accumulation at the ELA equals the sum of monthly snow melt.

Our relation between annual accumulation and summer temperature at the ELA (Fig. 2) is in general agreement with the range of values in Figure 2 of Ohmura et al. (1992). However, the latter refers to "winter mass balance plus summer precipitation", which they equate to "annual total precipitation".

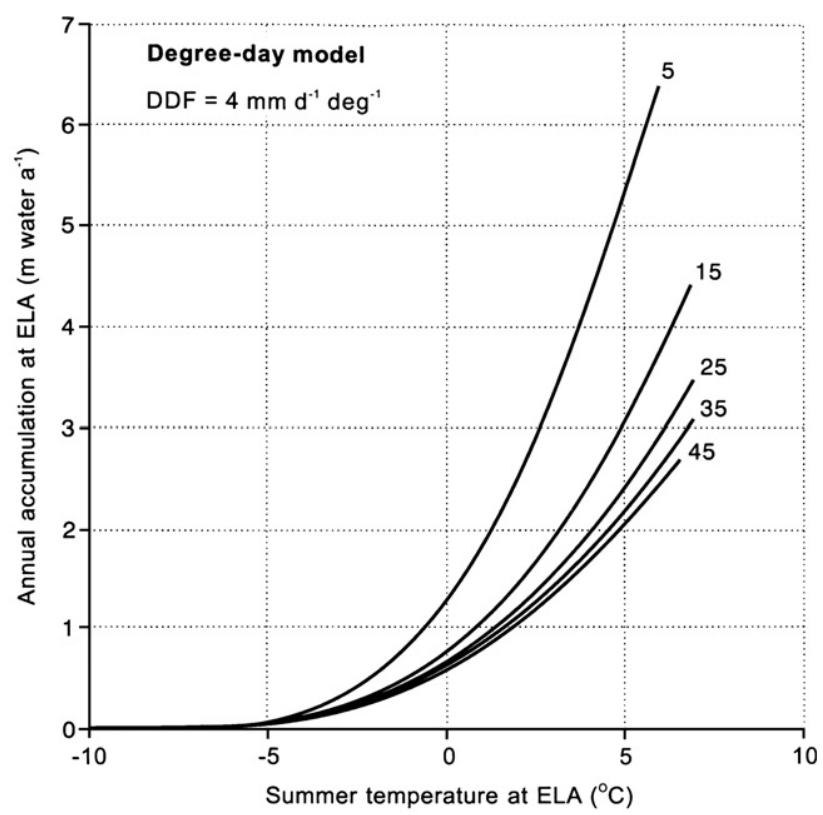

Figure 2. Annual accumulation at the ELA as a function of summer mean temperature (June, July, August). The degree-day model was applied assuming a sinusoidal temperature variation throughout the year with annual temperature ranges of $5,15,25,35$ and $45^{\circ} \mathrm{C}$.
Also, temperature in Figure 2 of this paper attempts to account for a "glacier cooling effect" (Braithwaite, 1980; Braithwaite et al., 2003) while Ohmura et al. (1992) refer to "mean summer temperature in free atmosphere at ELA".

There is no single curve linking accumulation to summer temperature (Fig. 2) but there is a family of curves defined by annual temperature range. You could therefore expect a reasonably strong correlation between accumulation and summer temperature without taking account of the extra effect of temperature range. For a particular value of summer temperature, high annual temperature range favors lower accumulation than low temperature range. This is probably because high temperature range limits snow melt to the "summer period" (JuneAugust) while lower temperature range allows a greater amount of snow melt outside of the June-August period. The increase of accumulation in Figure 2 with decreasing temperature range therefore reflects the effect of this increasing snow melt outside June-August. For example, an annual temperature range of 35$45^{\circ} \mathrm{C}$ is characteristic of arctic glaciers like those on Axel Heiberg Island with very short melt season (ca. 27 days) at the ELA (Braithwaite and Raper, 2007). On the other hand, an annual temperature range of $5-15^{\circ} \mathrm{C}$ is characteristic of very maritime glaciers like those in New Zealand with long melt season (Braithwaite and Raper, 2007).

The curves in Figure 2 could be regarded as defining an envelope within which individual values will fall, but there is no simple relation between annual accumulation and annual mean temperature at the ELA (Fig. 3) calculated by the same model. The pattern in Figure 3 is unverifiable as the authors are unaware of any measured data for present-day glaciers.

Figures 2 and 3 illustrate the model but should not be taken too literally. For example, the model (Fig. 2) predicts very high accumulation (over $5 \mathrm{~m}$ w.e.) for high summer temperature (over $5^{\circ} \mathrm{C}$ ) and low annual temperature range $\left(5^{\circ} \mathrm{C}\right.$ ), such as on a very maritime glacier. However, Figure 3 shows that this can only be achieved with a very high annual temperature (well over $0^{\circ} \mathrm{C}$ ). The modeller may well ask if such a high accumulation of snow can really be achieved with such warm temperatures and may infer that high temperatures cannot prevail on a glacier with such a low annual temperature range. Pushing the argument further for tropical glaciers with very small annual temperature range, it could be possible to achieve a plausible annual accumulation of about $2 \mathrm{~m}$ w.e. with annual and summer (?) temperatures both around $0^{\circ} \mathrm{C}$. However, more research is needed on tropical glaciers.

\section{Reconstructing Pleistocene glaciers and climate in Greece}

The extent and distribution of the Pleistocene glaciers of Mount Tymphi is illustrated in Figure 1. During the Skamnellian Stage (MIS 12), valley glaciers and ice fields covered an area of $59.3 \mathrm{~km}^{2}$ on this mountain and had a mean ELA of $1741 \mathrm{~m}$ a.s.l. Smaller cirque and valley glaciers during the later Vlasian Stage (MIS 6) covered an area of $21.3 \mathrm{~km}^{2}$ with a mean ELA of $1862 \mathrm{~m}$ a.s.l. (Hughes et al., 2007). The last major glaciation in Greece, during the Tymphian Stage (MIS 5d-2), was characterized by higher and much smaller glaciers. At the last local glacier 


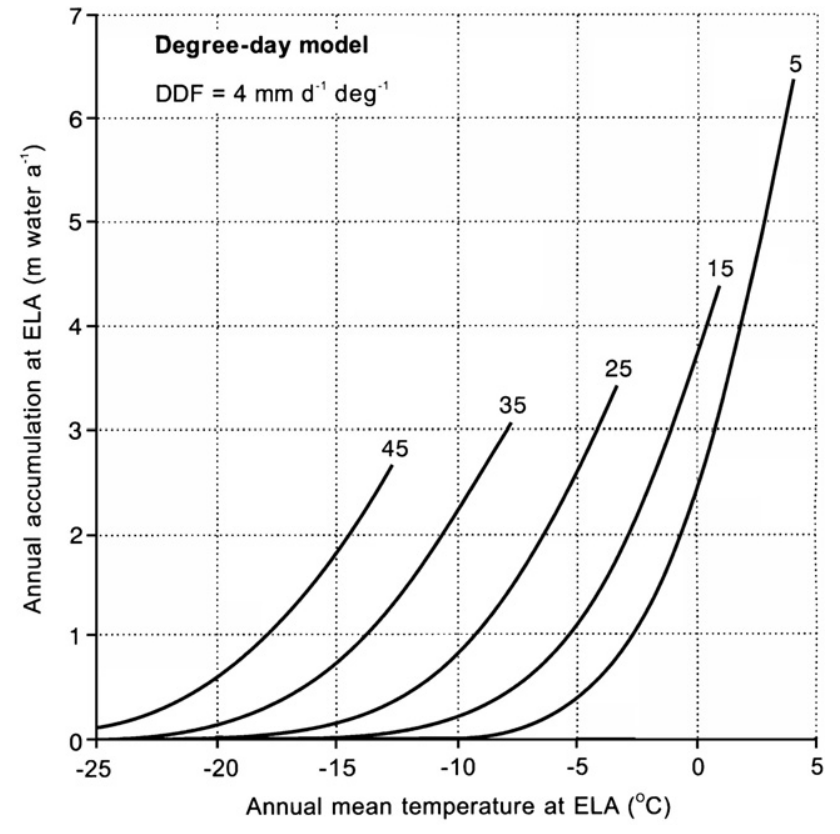

Figure 3. Annual accumulation at the ELA as a function of annual mean temperature (January to December). The degree-day model was applied assuming a sinusoidal temperature variation throughout the year with annual temperature ranges of $5,15,25,35$ and $45^{\circ} \mathrm{C}$.

maximum, glaciers on Mount Tymphi had a mean ELA of $2174 \mathrm{~m}$ a.s.l. and covered a total area of only $3.9 \mathrm{~km}^{2}$ (Hughes et al., 2006a). Late glacial glaciers did not form on Mount Tymphi but did on higher mountains such as Mount Smolikas, $15 \mathrm{~km}$ away across the Aoos valley to the northeast. Here, two small glaciers covered a combined area of only $0.2 \mathrm{~km}^{2}$ and had a mean ELA of $2420 \mathrm{~m}$ a.s.1. (Hughes et al., 2006d).

The degree-day model (Braithwaite et al., 2006; Braithwaite and Raper, 2007) is used to calculate the temperature (summer and annual means) at the ELA for the three glacial stages (Table 1). The temperature at the ELA is estimated by extrapolating temperature from the nearest grid square in a halfdegree gridded climatology (New et al., 1999) using a vertical lapse rate $\left(6.5^{\circ} \mathrm{K} \mathrm{km}^{-1}\right)$. The sum of positive temperature and the probability of freezing temperature at the ELA for each month are both calculated from monthly mean temperature, assuming that temperature is normally distributed within the month (Braithwaite, 1985). Snowmelt is calculated from the annual positive degree-day total using a degree-day factor of $4 \mathrm{~mm}$ day $^{-1}{ }^{\circ} \mathrm{K}^{-1}$ (Braithwaite et al., 2006) and accumulation at the ELA is set identical to calculated snow melt. Precipitation is calculated at the ELA from accumulation divided by the annual sum of monthly precipitation probability multiplied by monthly freezing probability, assuming that precipitation at the ELA follows the same distribution as precipitation in the gridded climatology. Calculated in this way, the annual precipitation at the ELA ("glacier precipitation") is generally greater than the precipitation in the gridded climatology ("grid precipitation") and this probably reflects a real increase of precipitation with altitude for most glaciers (Braithwaite et al., 2003).

Many climate variables, including mean summer temperature, mean annual temperature range and annual precipitation, are likely to have differed from the modern climate during the Pleistocene in Greece ( $c f$. Tzedakis et al., 2004; Hughes et al., 2006a,d, 2007). However, the degree-day model applied in the paper presented here simulates the temperature depression necessary to form glaciers in the Pindus Mountains under modern precipitation conditions and modern annual temperature range. The model assumes the present annual temperature range $\left(18.8^{\circ} \mathrm{C}\right)$ from the gridded climatology (New et al., 1999) and precipitation estimates of 2 to $2.5 \mathrm{~m}$ w.e. based on modern observations at stations in the Pindus Mountains (Fotiadi et al., 1999). The degree-day model is then run for the estimated ELAs in Table 1 for present temperature, and then the temperature is successively lowered in $1^{\circ} \mathrm{C}$ steps. This gives a table of precipitation and accumulation at the ELA as a function of temperature, from which temperatures (summer and annual) can be interpolated for precipitation values that are the same as today.

For roughly the same precipitation conditions as today, with annual precipitation of up to $2.5 \mathrm{~m}$ w.e., glaciers could have existed in the Pindus Mountains with summer temperature of about $3.6^{\circ} \mathrm{C}$ at the ELA with annual accumulation of $2 \mathrm{~m}$ w.e. Again, it must be stressed that modern precipitation at the sites of former Pleistocene glaciers may be much greater than 2 to $2.5 \mathrm{~m}$ w.e., since no climate data are available from highaltitude climate stations in the northern Pindus Mountains. Nevertheless, this range of values is probably representative of cold-stage precipitation values and corresponds with precipitation estimates calculated using empirical regressions, based on a known temperature value (Hughes et al., 2006a,d, 2007). A mean summer temperature of $3.6^{\circ} \mathrm{C}$ at the ELA with annual accumulation of $2 \mathrm{~m}$ w.e. corresponds quite well with presentday conditions at the ELA of glaciers in Scandinavia with similar annual temperature range (Braithwaite and Raper, 2007). From other work (Braithwaite et al., 2003), it is known that glaciers with similar accumulation have quite high mass balance sensitivity and could have advanced and/or retreated quite rapidly.

The degree-day model calculates that when annual precipitation is $2.5 \mathrm{~m}$ w.e., the annual accumulation value of $2 \mathrm{~m}$ w.e. corresponds with an annual mean temperature of $-4.0^{\circ} \mathrm{C}$ at the ELA (Figs. 2 and 3). This is similar to the mean annual temperature $\left(-4.2^{\circ} \mathrm{C}\right)$ calculated at the ELA for the Tymphian

Table 1

Palaeoclimate reconstructions for the different phases of glaciation in the Pindus Mountains (Hughes et al., 2006a,d, 2007) using the degree-day model

\begin{tabular}{llll}
\hline Stage & $\begin{array}{l}\text { Estimated ELA } \\
\text { (m a.s.1.) }\end{array}$ & $\begin{array}{l}\text { Present precipitation } \\
\text { (m w.e.) }\end{array}$ & $\begin{array}{l}\text { Temperature } \\
\text { depression }\left({ }^{\circ} \mathrm{C}\right)\end{array}$ \\
\hline $\begin{array}{l}\text { Tymphian } \\
\quad(\text { late glacial) }\end{array}$ & 2420 & $2.0-2.5$ & -5.3 to -4.4 \\
Tymphian (MIS 5d-2) & 2174 & $2.0-2.5$ & -6.9 to -6.0 \\
Vlasian (MIS 6) & 1862 & $2.0-2.5$ & -8.9 to -8.0 \\
Skamnellian (MIS 12) & 1741 & $2.0-2.5$ & -9.7 to -8.8 \\
\hline
\end{tabular}

Annual precipitation values of 2.0-2.5. $\mathrm{m}$ w.e. correspond with annual accumulation values of 1.7 to $2.0 \mathrm{~m}$ w.e. The degree-day model calculates that this range of annual accumulation values corresponds with annual mean temperatures of -4.8 to $-4.0^{\circ} \mathrm{C}$ at the ELA and summer temperatures of 2.8 to $3.6^{\circ} \mathrm{C}$ (Figs. 2 and 3 ). MIS $=$ marine isotope stage. 
Stage using periglacial evidence by Hughes et al. (2006a). By applying the degree-day model to the mean annual temperature calculated independently in Hughes et al. (2006a), accumulation can be estimated to have been $1.93 \mathrm{~m}$ w.e. and annual precipitation $2.35 \mathrm{~m}$ w.e., which is in good agreement with results in Table 1. Thus, mean annual temperatures derived from periglacial evidence potentially can be utilized by the degree-day model to calculate annual accumulation.

The glacier-climate reconstructions for Greece during three separate Pleistocene cold stages illustrate the magnitude of climate change needed to form glaciers of various sizes in the Pindus Mountains. For all cold-stage glacier maxima, the model assumes annual precipitation of 2.0 to $2.5 \mathrm{~m}$ w.e. at the ELA. However, cold-stage climates in the Mediterranean were characterized by highly variable moisture supply (Tzedakis et al., 2004), and there is evidence to suggest that different cold stages were wetter or drier overall than others (Ayalon et al., 2002; see discussion in Hughes et al., 2007). Nevertheless, it is highly unlikely that moisture supply during cold stages exceeded that during interglacials, such as the Holocene, largely because of much cooler surface waters in the Mediterranean Sea (Bigg, 1994). Thus, if it assumed that modern precipitation values were never exceeded during the different Pleistocene cold stages, then the temperature depressions indicated in Table 1 can be considered as minimum values. This is important because it provides a clear illustration of the severity of climate during the different glaciations. The Middle Pleistocene glaciations would have been particularly severe in terms of temperature, with the glacier maximum of the Skamnellian Stage (MIS 12) being the coldest recorded period of the last 430,000 yr with annual and summer temperatures at least $9.3^{\circ} \mathrm{C}$ colder than today (mean of 8.8 and $9.7^{\circ} \mathrm{C}$ to 1 decimal place). This temperature depression is less than that the $11.1^{\circ} \mathrm{C}$ calculated by Hughes et al. (2007) using the regression approach. However, this is partly because the earlier paper by Hughes et al. (2007) and others (Hughes et al., 2003, 2006a,d) compare reconstructed temperatures with those at Ioannina meteorological station and not with the gridded climatology of New et al. (1999). Nevertheless, the differences in temperature depressions in Table 1 are consistent in terms of demonstrating the severity of cold temperatures during MIS 12 compared with later cold stages.

It is clear that the coldest climates recorded by former glaciers in Greece occurred during the Middle Pleistocene with temperature depression of at least $9.3^{\circ} \mathrm{C}$ during the Skamnellian Stage (MIS 12). If the Skamnellian glaciation occurred under drier conditions than today, which is highly likely when considering that the lowest arboreal pollen percentages of the last 450,000 yr are recorded at Tenaghi Philippon during this interval (Tzedakis et al., 2003), then temperatures would have been depressed by significantly more than $9.3^{\circ} \mathrm{C}$. Both a combination of major glaciation in the uplands, severe cold and potentially dry conditions would have had catastrophic consequences for biota in the region. The refugial capacity of the Pindus Mountains would have been strained compared with later glaciations and the severity of the Skamnellian Stage glacial climate is likely to have impacted on evolutionary trends across Europe during the later Pleistocene.

\section{Conclusions}

A degree-day model to reconstruct former glacier-climate conditions provides a process-based approach utilizing detailed data on the relationship between glacier ablation and air temperature from modern glaciers. The degree-day model approach enables the processes of mass balance to be manipulated in a model simulation. A particular strength of the degree-day model is that it allows annual temperature data to be utilized to reconstruct mean summer temperatures and annual accumulation (and from this precipitation) in any formerly glaciated area. This is especially useful where periglacial evidence provides a record of permafrost and associated mean annual temperatures such as in Greece (Hughes et al., 2003). When applied to former glaciers in Greece, the degree-day model suggests that glacierclimate conditions during the Tymphian Stage (MIS 5d-2) glacier maximum were analogous with maritime Scandinavian glaciers, confirming earlier suggestions of Hughes et al. (2006a). The Middle Pleistocene glaciations were the coldest with the Skamnellian Stage (MIS 12) being the most severe of the last $430,000 \mathrm{yr}$. This has important implications for the availability of biotic refugia in the Pindus Mountains, the wider Balkans and also other mountainous peninsulas of southern Europe, all of which are thought to have been important regions of refugia during Pleistocene cold stages. A degree-day model approach helps to understand the significance of glaciation in understanding Earth climate history and in conjunction with other records provides a powerful tool for palaeoclimate research.

\section{Acknowledgments}

We would like to thank two anonymous referees for their very useful comments on an earlier draft of this paper. PDH was funded by a University of Cambridge Domestic Research Studentship (2001-2004) and a University of Manchester Research Fellowship (2004-2006). Uranium-series support was provided by a NERC award (Reference Number: IP/754/0302) and undertaken at the Open University Uranium Series Facility in Milton Keynes. All field work was undertaken with permission of the Institute of Geological and Mineral Exploration (IGME) of Greece. Professor P.L. Gibbard (University of Cambridge) and Dr. J.C. Woodward (The University of Manchester) are thanked for their help in establishing the glacial history of Greece.

\section{References}

Ahlmann, H.W., 1924. Le niveau de glaciation comme fonction de l'accumulation d'humidité sous forme solide. Geografiska Annaler 6, 223-272.

Ahlmann, H.W., 1948. Glaciological research on the North Atlantic Coasts. Royal Geographical Society, London. Research Series 1.

Ayalon, A., Bar-Matthews, M., Kaufman, A., 2002. Climatic conditions during marine isotope stage 6 in the eastern Mediterranean from the isotopic composition of speleothems of Soreq Cave. Geology 30, 303-306.

Ballantyne, C.K., 1989. The Loch Lomond Readvance on the Isle of Skye, Scotland: Glacier reconstruction and palaeoclimatic implications. Journal of Quaternary Science 4, 95-108.

Ballantyne, C.K., 2002a. The Loch Lomond Readvance on the Isle of Mull, Scotland: Glacier reconstruction and palaeoclimatic implications. Journal of Quaternary Science 17, 759-771. 
Ballantyne, C.K., 2002b. Paraglacial geomorphology. Quaternary Science Reviews 21, 1935-2017.

Bigg, G.R., 1994. An ocean circulation model view of the glacial Mediterranean thermohaline circulation. Paleoceanography 9, 705-722.

Braithwaite, R.J., 1980. On glacier energy balance, ablation and air temperature. Journal of Glaciology 27, 381-391.

Braithwaite, R.J., 1985. Calculation of degree-days for glacier-climate research. Zeitschrift für Gletscherkunde und Glazialgeologie 20, 1-8.

Braithwaite, R.J., 1995. Positive degree-day factors for ablation on the Greenland ice sheet studied by energy-balance modelling. Journal of Glaciology 41 , 153-160.

Braithwaite, R.J., Raper, S.C.B., 2007. Glaciological conditions in seven contrasting regions estimated with the degree-day model. Annals of Glaciology 46, 297-302.

Braithwaite, R.J., Zhang, Y., Raper, S.C.B., 2003. Temperature sensitivity of the mass balance of mountain glaciers and ice caps as a climatological characteristic. Zeitschrift für Gletscherkunde und Glazialgeologie 38, 35-61.

Braithwaite, R.J., Raper, S.C.B., Chutko, K., 2006. Accumulation at the equilibrium line altitude of glaciers inferred from a degree-day model and tested against field observations. Annals of Glaciology 43, 329-334.

Brugger, K.A., 2006. Late Pleistocene climate inferred from the reconstruction of the Taylor River glacier complex, southern Sawatch Range, Colorado. Geomorphology 75, 318-329.

Church, M., Ryder, J.M., 1972. Paraglacial sedimentation, a consideration of fluvial processes conditioned by glaciation. Geological Society of America Bulletin 83, 3059-3072.

Fotiadi, A.K., Metaxas, D.A., Bartzokas, A., 1999. A statistical study of precipitation in northwest Greece. International Journal of Climatology 19, 1221-1232.

Frogley, M.R., Griffiths, H.I., Heaton, T.H.E., 2001. Historical biogeography and Late Quaternary environmental change of Lake Pamvotis, Ioannina (north-western Greece): evidence from ostracods. Journal of Biogeography $28,745-756$.

Haeberli, W., 1985. Creep of mountain permafrost: Internal structure and flow of alpine rock glaciers. Mitteilungen der Versuchsanstalt für Wasserbau, Hydrologie und Glaziologie 77 (Zürich).

Hughes, P.D., 2002. Loch Lomond Stadial glaciers in the Aran and Arenig Mountains, North Wales. Geological Journal 37, 9-15.

Hughes, P.D., Gibbard, P.L., Woodward, J.C., 2003. Relict rock glaciers as indicators of Mediterranean palaeoclimate during the Last Glacial Maximum (Late Würmian) of northwest Greece. Journal of Quaternary Science 18, 431-440.

Hughes, P.D., Woodward, J.C., Gibbard, P.L., 2006a. Late Pleistocene glaciers and climate in the Mediterranean region. Global and Planetary Change 50, $83-98$.

Hughes, P.D., Woodward, J.C., Gibbard, P.L., 2006b. Quaternary glacial history of the Mediterranean mountains. Progress in Physical Geography 30, 334-364.

Hughes, P.D., Woodward, J.C., Gibbard, P.L., Macklin, M.G., Gilmour, M.A., Smith, G.R., 2006c. The glacial history of the Pindus Mountains, Greece. Journal of Geology 114, 414-434.

Hughes, P.D., Woodward, J.C., Gibbard, P.L., 2006d. The last glaciers of Greece. Zeitschrift für Geomorphologie 50, 37-61.

Hughes, P.D., Woodward, J.C., Gibbard, P.L., 2007. Middle Pleistocene cold stage climates in the Mediterranean: New evidence from the glacial record. Earth and Planetary Science Letters 253, 50-56.

Humlum, O., 1998. The climatic significance of rock glaciers. Permafrost and Periglacial Processes 9, 375-395.

Huybrechts, P., Letreguilly, A., Reeh, N., 1991. The Greenland ice sheet and greenhouse warming. Palaeogeography, Palaeoclimatology, Palaeocology 89, 399-412.
King, G., Bailey, G., 1985. The palaeoenvironment of some archaeological sites in Greece: the influence of accumulated uplift in a seismically active region. Proceedings of the Prehistoric Society 51, 273-282.

Leonard, E., 1989. Climatic change in the Colorado Rocky Mountains: Estimates based on modern climate at Late Pleistocene equilibrium line altitudes. Arctic and Alpine Research 21, 245-255.

Loewe, F., 1971. Considerations of the origin of the Quaternary ice-sheet in North America. Arctic and Alpine Research 3, 331-344.

Miller, R.F., Elias, S.A., 2000. Late-glacial climate in the Maritimes Region, Canada, reconstructed from mutual climatic range analysis of fossil Coleoptera. Boreas 29, 79-88.

New, M., Hulme, M., Jones, P., 1999. Representing twentieth century spacetime climate variability: I. Development of a 1961-1990 mean monthly terrestrial climatology. Journal of Climate 12, 829-856.

Ohmura, A., Kasser, P., Funk, M., 1992. Climate at the equilibrium line of glaciers. Journal of Glaciology 38, 397-411.

Osmaston, H., 2002. The nature, extents and climates of former Quaternary tropical glaciers, with reference to the East African Mountains. In: Kaser, G., Osmaston, H. (Eds.), Tropical glaciers. Cambridge University Press, Cambridge, pp. 149-192 (Chapter 9).

Peyron, O., Guiot, J., Cheddadi, R., Tarasov, P., Reille, M., de Beaulieu, J.-L., Bottema, S., Andrieu, V., 1998. Climatic reconstruction in Europe for 18,000 YR B.P. from pollen data. Quaternary Research 49, 183-196.

Raper, S.C.B., Braithwaite, R.J., 2006. Low sea level rise projections from mountain glaciers and ice caps under global warming. Nature 439, 311-313.

Reeh, N., 1989. Parameterization of melt rate and surface temperature on the Greenland ice sheet. Polarforschung 59, 113-128.

Sissons, J.B., 1974. A late-glacial ice-cap in the central Grampians, Scotland. Transactions of the Institute of British Geographers 62, 95-114.

Sissons, J.B., 1977. The Loch Lomond Advance in the Northern Mainland of Scotland. In: Gray, J.M., Lowe, J.J. (Eds.), Studies in the Scottish Lateglacial Environment. Pergamon Press, Oxford, pp. 45-59.

Sutherland, D.G., 1984. Modern glacier characteristics as a basis for inferring former climates with particular reference to the Loch Lomond Stadial. Quaternary Science Reviews 3, 291-309.

Tzedakis, P.C., McManus, J.F., Hooghiemstra, H., Oppo, D.W., Wijmstra, T.A., 2003. Comparison of changes in orbital and suborbital frequencies over the last 450,000 years. Earth and Planetary Science Letters 212, 197-212.

Tzedakis, P.C., Frogley, M.R., Lawson, I.T., Preece, R.C., Cacho, I., de Abreu, L., 2004. Ecological thresholds and patterns of millennial-scale climate variability: The response of vegetation in Greece during the last glacial period. Geology 32, 109-112.

van Andel, T.H., Shackleton, J.C., 1982. Late Paleolithic and mesolithic coastlines of Greece and the Aegean. Journal of Field Archaeology 9, 445-454.

Waltham, A.C., 1978. The caves and karst of Astraka, Greece. Transactions of the British Cave Research Association 5, 1-12.

Woodward, J.C., Macklin, M.G., Smith, G.R., 2004. Pleistocene glaciation in the mountains of Greece. In: Ehlers, J., Gibbard, P.L. (Eds.), Quaternary Glaciations - Extent and Chronology: Part 1. Elsevier, Amsterdam, pp. $155-173$.

World Meteorological Organisation 1998. World Meteorological Organisation, 1961-1990 global climate normals, Electronic Resource, National Climatic Data Center, US, Asheville, NC (1998) CD-ROM.

Yokoyama, Y., Lambeck, K., De Deckker, P., Johnston, P., Fifield, K., 2000. Timing of the Last Glacial Maximum from observed sea-level minima. Nature 406, 713-716. 